\title{
The effect of Diesel-Methanol Blends with Volumetric Proportions on the Performance and Emissions of a Diesel Engine
}

\author{
Adnan BERBER \\ Department of Mechanical Engineering, Necmettin Erbakan University, Konya, Turkey, E-mail: aberber@erbakan.edu.tr \\ crossref http://dx.doi.org/10.5755/j01.mech.25.5.22954
}

\section{Introduction}

Fossil fuels, which meet today's energy needs in a considerable extent, are being depleted rapidly. Also, the products resulting from combustion of these fuels lead to critical problems related to all human beings such as, greenhouse effect, ozone-depleting, acid rains, air pollution.

Alternative fuels, especially alcohol fuels, are known to be a good potential to reduce the environmental and economic concerns as well as to reduce exhaust emissions and to facilitate the sustainability of energy sources.

The increase of use of renewable fuels in vehicles, based on the recent regulations results in the growing interest to the alternative fuels. From the conducted researches in the automotive field over the last 30 years, it is claimed that alcohol fuels, methanol and ethanol in particular, are compatible with the hydrocarbon fuel blends, and enhance the nitrogen oxide (NOx) and particular substance (PM) emissions [1].

Alcohol additives including methanol and ethanol are very easy to mix with the pure biodiesel, and help to decrease the higher viscosity and density values of the biodiesel compared to standard diesel. The additives enhance the combustion efficiency and produce lower exhaust gas emissions. These alcohols have approximately 35\% and $30 \%$ higher oxygen so that it helps to achieve better combustion quality in the diesel engine [2].

The commonly used short chain alcohols are methanol, ethanol, propanol and butanol. Esterification product is not dependent on the type of alcohol. Because of this reason, cost and performance can be accepted as criteria for the selection of the alcohol type. Among these alcohols, methanol is generally chosen because it has a low cost [3].

Methanol has a long history of use in racing vehicles where it is valued both for its power producing properties and its safety aspects (methanol is harder to ignite, creates less radiant heat, and burns without producing black smoke). The capacity of methanol to replace petroleum fuels has long been known. While the future presence of crude oil is increasingly being questioned, methanol has received renewed interest since it is easily made from distant natural gas and from the broad coal and biomass sources around the world. Much work has already been done around the world to determine the appropriate ways of designing and modifying vehicles for the use of methanol as a clean fuel or as a mixture with diesel [4].

Today, the interest to alternative fuels is continuously increasing due to the price rise and the environmental distributions in the transportation sector. Methanol is one of the alternative fuels, which can be used in internal combustion engines along with different methods. Methanol can typically be produced by distilling fossil fuels consisting of methyl alcohol such as wood and coal under heat treatment, or by distilling natural gas with different methods, or synthesizing $\mathrm{CO}$ and $\mathrm{H} 2$ in a catalytic environment.

The Diesel-Methanol blends need to be improved to minimize the negative impacts of diesel fuel in transportation industry.

It is possible to use methanol in vehicles using different methods. As an example, methanol can be used directly as fuel in internal combustion engines. However, this type of use may not be chosen because of the issue of excess demand and insufficient supply. Instead, the addition of methanol to diesel fuel in a specified proportion would be reasonable both for enhancing diesel emissions and for ensuring sufficient supply of methanol. Unburned hydrocarbon emissions are not observed because combustion of methanol is nearly completed and thus there is no particles. Methanol has a low flame temperature compared to gasoline so that it provides better burning and lower $\mathrm{CO}, \mathrm{CO} 2$ and NOx emissions [5].

Nowadays, methanol has been used in internal combustion engines because it has many advantages such as clear, environment-friendly, compatibility with different methods, ease of storage.

Many research on the use of methanol as fuel in both diesel and gasoline engines has been addressed in the literature. At first, these works have been mostly focused on experimental studies. Recently, in parallel with the computational developments, both the experimental and theoretical (which is based on mathematical methods) works on this direction has been increasingly taken place in the current literature.

Some current studies about Diesel-Methanol blends found in the literature are presented as follow.

Najafi et al. used a four stroke, four cylinder, direct injection diesel engine using methanol blended diesel fuel at various ratios (methanol to diesel): 10:90, 20:80 and 30:70. The results indicated that the lower output power and torque was produced for diesel fuel compared with the methanolblended fuels at all of ratios. The exhaust temperature for the blended fuel was lower compared to fuel diesel, and the best mixing ratio was found to be $10 \%$ of methanol $+90 \%$ of diesel fuel for the minimum exhaust temperature [6]. Suresh et al. prepared a single cylinder vertical air cooled diesel engine for the use of methanol. They investigated the performance, emission, and combustion characteristics of the engine using the methanol additive. The brake thermal efficiency enhanced by $3 \%$ in the dual fuel mode, and also resulted in the hydrocarbon, smoke emissions, and carbon monoxide in a decrease of $69 \%, 50 \%$ and $9 \%$ respectively [7]. Chu Weitao examined the effect of diesel-methanol blends (M0, M5and M15) on diesel engine performance us- 
ing a single-engine ZS195. According to the experiment results, they claim that the addition of methanol made the driving force of the engine weaker, improved fuel consumption, smoke and $\mathrm{CO}$ emissions. Also NOx emissions were expressed to be high at M5 blend; however, to be improved at M15 blend [8]. Joshua M. P. et al. examined the effects of M10, M20 and M30 on a four stroke, single cylinder, water cooled diesel engine. In this work, the performance and emission characteristics of diesel-methanol blends were investigated, and the results are analyzed in detail [9]. Kwanchareon et al. [10] examined the effect of diesel-biodieselethanol blends on solubility and emission characteristics of a diesel engine. They claim that the $\mathrm{CO}$ and $\mathrm{HC}$ emissions decreased significantly at high load while NOx increased compared with those blend fuels. Murat et al. [11] examined the effect of methanol and diesel fuel blends on the performance and emissions of a diesel engine which is four cylinder, four stroke, direct injection, turbocharged. Carbon monoxide and hydrocarbons emissions decreased with the increment of methanol amount when compared with those of diesel fuel. Gopinath et al. [12] examined the CI engine performance and emission parameters using corn oil Methyl Ester as biodiesel fuel. Arumugam et al. [13] carried out an experimental investigation on the efficient combustion of blends of Straight Vegetable Oil (SVO) with diesel, using a noncommercial hot water generator.

As can be understood from the literature, the potential of various fuel blends such as methanol-diesel blends, still needs to be investigated to enhance the performance of the compression-ignition engines so that this type blends have gained a great interest in the recent years.

Also, it can be expressed from the literature that diesel-methanol blends have a good potential both for reducing emissions and for enhancing the engine performance. From that point, we aim to optimize the diesel-methanol blend so as to enhance $\mathrm{CO}, \mathrm{CO} 2, \mathrm{HC}$, NOx and smoke emissions, and to increase the engine performance. In this study, four stroke, single cylinder, water cooled and direct injection engine is selected for carrying out the required experiments. In addition, the responses of a commercial single-cylinder CI engine in the different proportions of diesel- methanol blends are investigated.

\section{Materials and methods}

The properties of diesel fuel and methanol used in the experiments are respectively given to be Euro-diesel, and the Merck brand and degree of purity of 99\%. Commercial Euro diesel (cED) purchased from a local petrol station was used as the primary fuel in the experiments. Methanol is introduced to diesel fuel by following the injection procedure, and all of these blends are mixed in a closed vessel for two hours at 45-50 oC. The volumetric proportions of these blends are given to be M5: $95 \%$ diesel fuel $+5 \%$ methanol; M10: $90 \%$ diesel fuel $+10 \%$ methanol; M15: $85 \%$ diesel fuel $+15 \%$ methanol. No visible phase separation for the test fuels was observed after a retention time of 20 days in a fermentation vessel. Some properties of the test fuels used in the experiment are shown in Table 1. A comparison of the thermo-physical properties of methanol and diesel is presented in Table 2. The fuel properties were measured in the Biodiesel Laboratory of Agriculture Faculty of Selcuk University. Fig. 1 shows a schematic diagram of the experimental setup.

The Antor 3LD510 model test engine used in the experiment, which is four stroke, single cylinder, water cooled and direct injection engine, is shown in Fig. 2. The features of the test engine used in this experiment are given in the Table 3. In this experiment, an exhaust gas analyzer (MRU Optima 7 model) was used. A turbidimeter (Bosch-RTM 430 model-turbidimetric measurement module) was used to measure smoke emission. Calibrations of the two devices were conducted before the tests. The properties of the two devices and the measurement devices, such as measurement ranges, precisions, speed ranges, etc., are presented in Table 4 and 5, respectively.

In the experiment, a NF150 brand hydraulic dynamometer to load the engine, a CAS-SBA 200L brand loadcell to measure the torque, and a Dikomsan / FGH-3000 brand digital scale $( \pm 0.01 \mathrm{~g})$ to measure the fuel consumption were used.

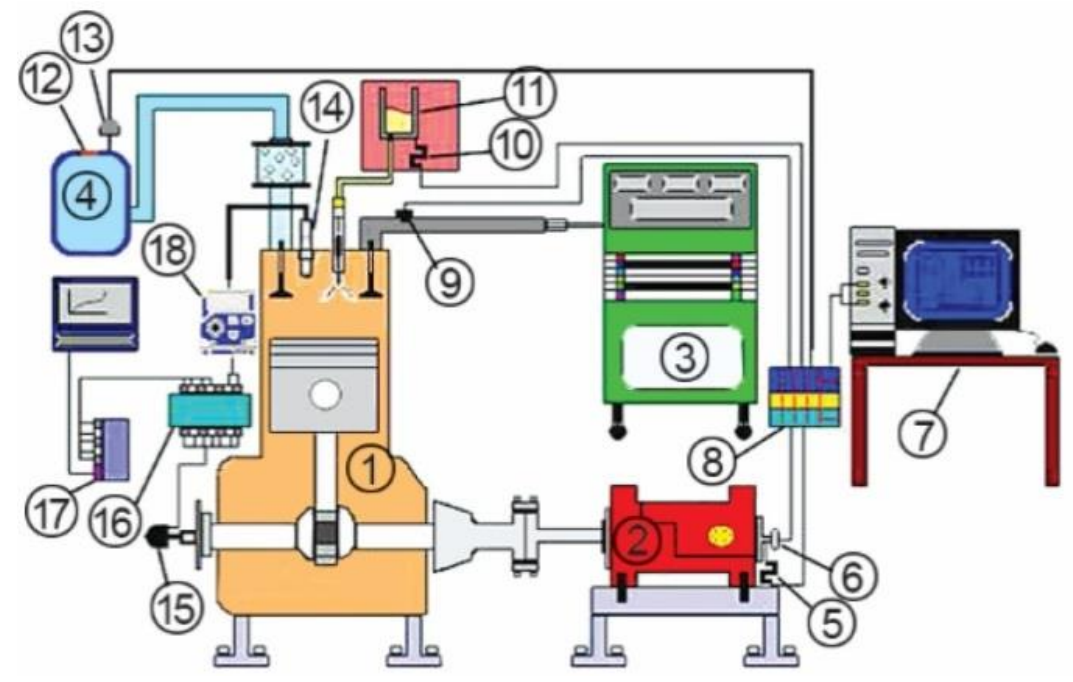

Fig. 1 Schematic diagram of the experiment setup: 1 - Test engine, 2 - HYD dynamometer, 3 - Exhaust gas analyzer, 4 - Air balance tank, 5 - Load cell for torque, 6 - Speed sensor, 7 -Load controller, 8 - Data acquisition, 9 - PT100 for exhaust gas temperature, 10 - Load cell for fuel consumption, 11 - Fuel tank, 12 - Orifices plate,- 13-Differential pressure transducer- in-cylinder14-Pressure sensor, 15 - encoder, 16 - Combustion analyzer, 17 - Data acquisition, 18 - Amplifier 
Table 1

Some properties of test fuels

\begin{tabular}{|l|c|c|c|c|c|c|}
\hline Property & Unit & Euro Dizel & Methanol & M5 & M10 & M15 \\
\hline Density $\left(\right.$ at $\left.15{ }^{\circ} \mathrm{C}\right)$ & $\mathrm{kg} / \mathrm{m}^{3}$ & 833 & 791.96 & 830.09 & 828.04 & 825.98 \\
Viscosity $\left(\right.$ at $\left.40^{\circ} \mathrm{C}\right)$ & $\mathrm{mm}^{2} / \mathrm{s}$ & 2.8 & 0.58 & 1.94 & 1.83 & 1.72 \\
Cetan index & - & 53.5 & - & 50.8 & 49.6 & 47.9 \\
Lower Heating Value & $\mathrm{MJ} / \mathrm{kg}$ & 43.47 & 19.83 & 41.54 & 40.36 & 39.17 \\
Corrosion of $\mathrm{Cu}\left(3 \mathrm{~h}\right.$ at $\left.50^{\circ} \mathrm{C}\right)$ & - & $1 \mathrm{a}$ & $1 \mathrm{a}$ & $1 \mathrm{a}$ & $1 \mathrm{a}$ & $1 \mathrm{a}$ \\
\hline
\end{tabular}

Table 2

Comparison of thermo-physical properties of methanol and diesel [14-16]

\begin{tabular}{|l|l|l|}
\hline Properties & Methanol & Diesel \\
\hline Chemical Formula & $\mathrm{CH} 3 \mathrm{OH}$ & $\mathrm{C} 12 \mathrm{H} 26-\mathrm{C} 14 \mathrm{H} 30$ \\
Molecular weight $\left(\mathrm{g} \mathrm{mol}^{-1}\right)$ & 32 & $190-220$ \\
Density @ 20 ${ }^{\circ} \mathrm{C}\left(\mathrm{g} \mathrm{cm}^{-3}\right)$ & 0.790 & 0.840 \\
Viscosity @ $20^{\circ} \mathrm{C}(\mathrm{m} \mathrm{Pa} \mathrm{S})$ & 0.59 & 2.8 \\
Carbon Content $(\% \mathrm{wt})$ & 37.5 & 86 \\
Hydrogen Content $(\% \mathrm{wt})$ & 12.5 & 14 \\
Oxygen Content $(\% \mathrm{wt})$ & 50 & 0 \\
Sulfur content $(\mathrm{ppm} w \mathrm{wt})$ & 0 & $<350$ \\
Cetane number & $<5$ & 51 \\
Auto ignition temperature $\left({ }^{\circ} \mathrm{C}\right)$ & 464 & 316 \\
Heat of evaporization $(\mathrm{kJ} / \mathrm{kg})$ & 1178 & 260 \\
Stoichiometric fuel/air ratio & 0.15393 & 0.06924 \\
Lower heating value $(\mathrm{MJ} / \mathrm{kg})$ & 19.7 & 42.5 \\
Flash Point $\left({ }^{\circ} \mathrm{C}\right)$ & 11 & 52 \\
\hline
\end{tabular}

Table 3

Table 4

Features of the test engine

\begin{tabular}{|l|l|}
\hline Model & Antor 3LD510 \\
\hline Cylinder number & 1 \\
\hline Total Cylinder Volume, $\mathrm{cm}^{3}$ & 510 \\
\hline BoreX Stroke, mm X mm & 85 X 90 \\
\hline Compression Ratio & $17.5: 1$ \\
\hline Maximum Engine Speed, $\mathrm{rpm}$ & 3300 \\
\hline Maximum Engine Torque, Nm & 32.8 \\
\hline Maximum Engine Power, $\mathrm{kW}$ & 9 \\
\hline Injector Pressure, bar & 190 \\
\hline
\end{tabular}

Technical features of emission devices

\begin{tabular}{|l|c|c|}
\hline Gases & $\begin{array}{c}\text { Measurement } \\
\text { Range }\end{array}$ & Precision \\
\hline $\mathrm{CO} 2, \% \mathrm{v} / \mathrm{v}$ & $0-18$ & 0.01 \\
$\mathrm{CO}, \% \mathrm{v} / \mathrm{v}$ & $0-10$ & 0.001 \\
$\mathrm{NOx}, \mathrm{ppm}$ & $0-5000$ & $1 \mathrm{ppm}$ \\
Smoke (k), 1/m & $0-10$ & 0.0 "1 \\
Exhaust Gas Temperature, ${ }^{\circ} \mathrm{C}$ & $0-1000$ & 1 \\
\hline
\end{tabular}

Features of measurement equipment

Table 5

\begin{tabular}{|c|c|c|c|c|c|c|}
\hline \multicolumn{3}{|c|}{ Hydraulic dynamometer } & \multicolumn{4}{|c|}{ Pressure sensor (Kistler - 6052C) } \\
\hline Mark - model & Range of speed [rpm] & Range of torque[Nm] & \multirow{2}{*}{\multicolumn{2}{|c|}{ Type }} & $\begin{array}{c}\text { Range of measure } \\
\text { [bar] }\end{array}$ & $\begin{array}{c}\text { Working temper- } \\
\text { ature }\left[{ }^{\circ} \mathrm{C}\right]\end{array}$ \\
\hline $\begin{array}{l}\text { Net fren- } \\
\text { NF150 }\end{array}$ & $0-6500$ & $0-450$ & & & & \\
\hline \multicolumn{3}{|c|}{ Load cell for torque } & \multicolumn{4}{|c|}{ Amplifier (Kistler - 5018A) } \\
\hline Mark - model & \multicolumn{2}{|c|}{ Range of weight $[\mathrm{kg}]$} & \multicolumn{2}{|c|}{$\begin{array}{l}\text { Channel number / } \\
\text { working temp. }\left[{ }^{\circ} \mathrm{C}\right]\end{array}$} & $\begin{array}{c}\text { Range of measure } \\
{[\mathrm{pC}]}\end{array}$ & $\begin{array}{c}\text { Output signal [v]/ } \\
\text { Frekans }[\mathrm{kHz}]\end{array}$ \\
\hline $\begin{array}{l}\mathrm{CAS}-\mathrm{SBA} \\
200 \mathrm{~L}\end{array}$ & \multicolumn{2}{|c|}{$0-200$} & \multicolumn{2}{|c|}{$1 / 0-50$} & $2-2200000$ & $-10-10 / 0-200$ \\
\hline \multicolumn{3}{|c|}{ Load cell for fuel consumption } & \multicolumn{4}{|c|}{ Encoder } \\
\hline Mark-model & \multicolumn{2}{|c|}{ Range of weight $[\mathrm{kg}]$} & \multicolumn{2}{|c|}{ Mark - model } & $\begin{array}{l}\text { Working tempera- } \\
\text { ture }\left[{ }^{\circ} \mathrm{C}\right]\end{array}$ & $\begin{array}{l}\text { Range of meas- } \\
\text { ure [rpm] }\end{array}$ \\
\hline $\begin{array}{c}\mathrm{CAS}-\mathrm{BCL}- \\
1 \mathrm{~L}\end{array}$ & \multicolumn{2}{|c|}{$0-3$} & \multicolumn{2}{|c|}{$\begin{array}{c}\text { Kübler - Sendix } \\
5000\end{array}$} & $-40-85$ & $0-12000$ \\
\hline \multicolumn{3}{|c|}{ Differential pressure transmitter for air consumption } & \multicolumn{4}{|c|}{ Gas analyzer } \\
\hline Mark - model & \multicolumn{2}{|c|}{ Range of weight $[\mathrm{kg}]$} & $\mathrm{CO}(\mathrm{v} / \mathrm{v})$ & $\mathrm{HC}[\mathrm{ppm}]$ & NO [ppm] & Smoke opacity [\%] \\
\hline BD-DMD 341 & \multicolumn{2}{|c|}{$0-1000$} & $0-10$ & $0-9999$ & $0-5000$ & $0-100$ \\
\hline
\end{tabular}

The blends are mixed one more time to prevent the probability to occur a separation problem during experiments. Experiments were carried out in the laboratory of
Department of Automotive Technologies, Vocational School of Technical Sciences of Aksaray University. The engine performances and exhaust emissions at full load and 
constant revolutions starting from $1000 \mathrm{rpm}$ to $3000 \mathrm{rpm}$ were measured by controlling dynamometer load. All of the experiments were separately implemented for M5, M10 and M15 blends consisting of $100 \%$ euro-diesel fuel.

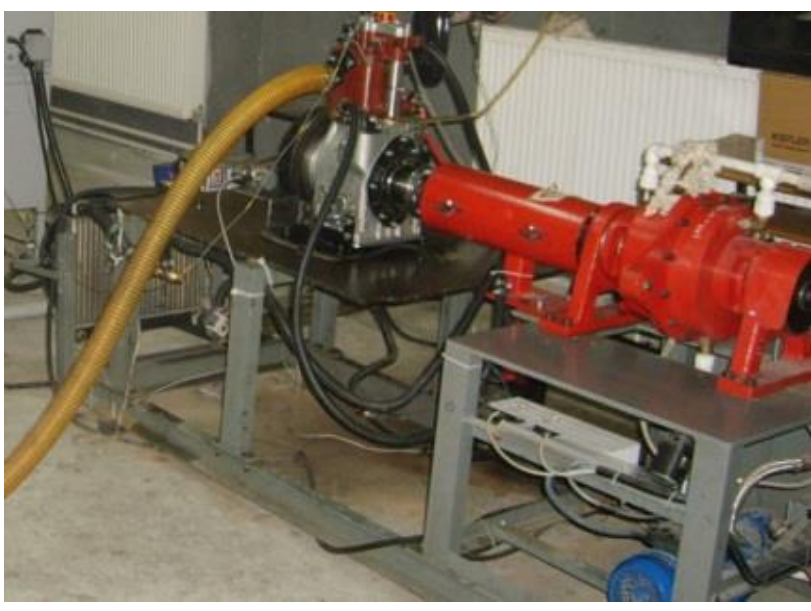

a

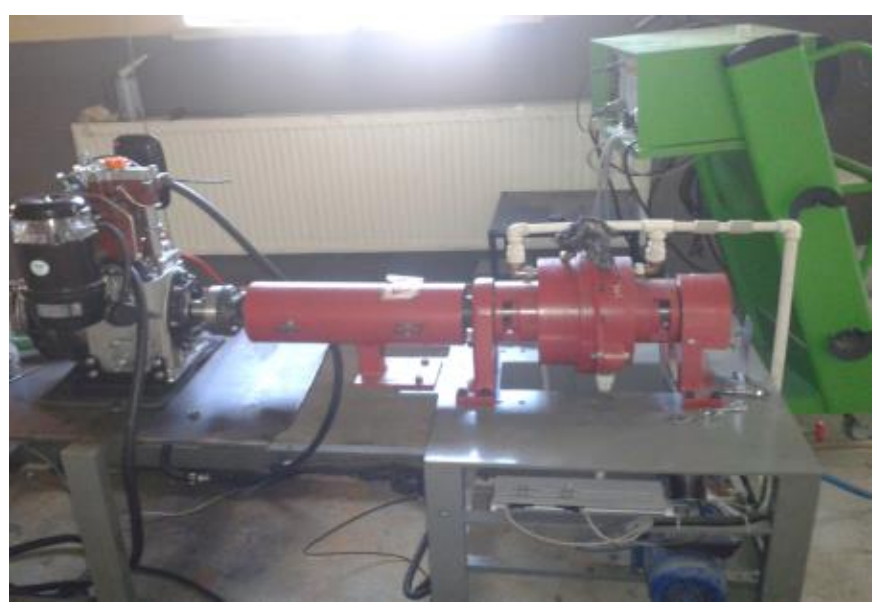

$\mathrm{b}$

Fig. 2 Test engine and experimental setup

\section{Results}

In this work, the effect of the addition of methanol to diesel fuel on the performance and exhaust emissions of a diesel engine was investigated. The engine performance parameters are engine torque and specific fuel consumption, and the exhaust emission parameters are $\mathrm{CO} 2, \mathrm{CO}$, exhaust gas temperature, NOx and emission of smoke opacity.

Fig. 3 shows the effects of the addition of methanol to diesel fuel on the engine performance. Because methanol has lower heating value than diesel fuel, the addition of methanol affects negatively the engine torque and its specific fuel consumption. With the decrease of heating values of the blends, the engine torque values of the blends with $5 \%-10 \%-15 \%$ methanol result in averagely a decrease of $6.27 \%, 8.84 \%$ and $13.07 \%$ compared to those of the diesel fuel. The values of specific fuel consumption of the blends were observed to be averagely the increase of $5.67 \%, 7.8 \%$ and $12.54 \%$.

Fig. 4 represents the values of $\mathrm{CO} 2$ emissions belonging to the test fuels. $\mathrm{CO} 2$ is one of greenhouse gases which are released into the atmosphere so much, and cause global warming and climate change. With the industrial revolution, the use of fossil fuels have increased; thus, the $\mathrm{CO} 2$ concentration in the atmosphere has increased rapidly [1-3].

Scientists have been keeping an eye on the $\mathrm{CO} 2$ level in the atmosphere since it is directly related to the climate change. Researchers put forward many solutions for controlling especially the $\mathrm{CO} 2$ concentration from road vehicles. Also governments have put restrictions on the emissions that are one of the most important reasons of the global warming [4].

Methanol reduces the $\mathrm{CO} 2$ values; in particular, the increase in the proportion of methanol reduces the $\mathrm{CO} 2$ emission. The addition of methanol results in an average decrease of $2.32 \%, 3.39 \%$ and $5.04 \%$ in the $\mathrm{CO} 2$ emissions of the blends. The most important reason of the decrease in the $\mathrm{CO} 2$ emission is that the $\mathrm{C}$ atoms in the methanol are less than those of diesel fuel.

Because the $\mathrm{CO}$ gas has hazardous nature and human exposure to the gas is fatal, there have been a lot of efforts conducted on reducing the gas emitted from vehicles [5]. CO gas, which is produced from combustion, indicates that the oxygen is not sufficient during the combustion so that all of $\mathrm{C}$ atoms are not converted into $\mathrm{CO} 2[6,7]$.

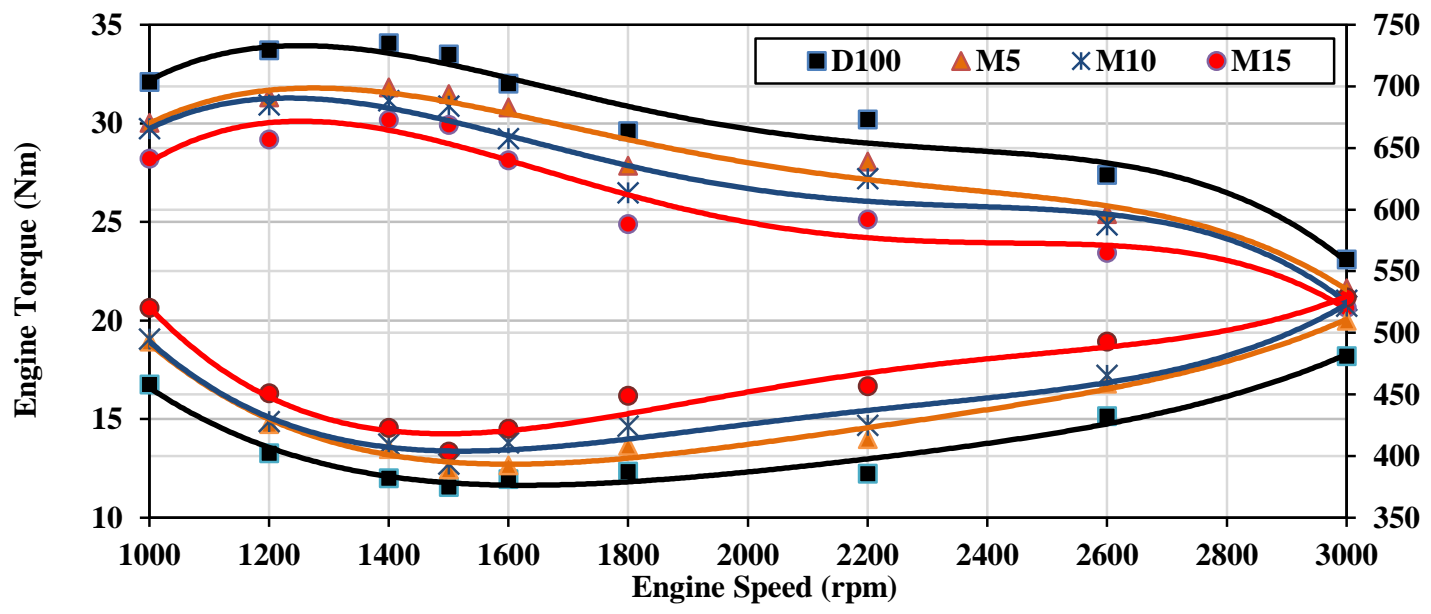

Fig. 3 The effects of the addition of methanol to diesel fuel on the engine performance 


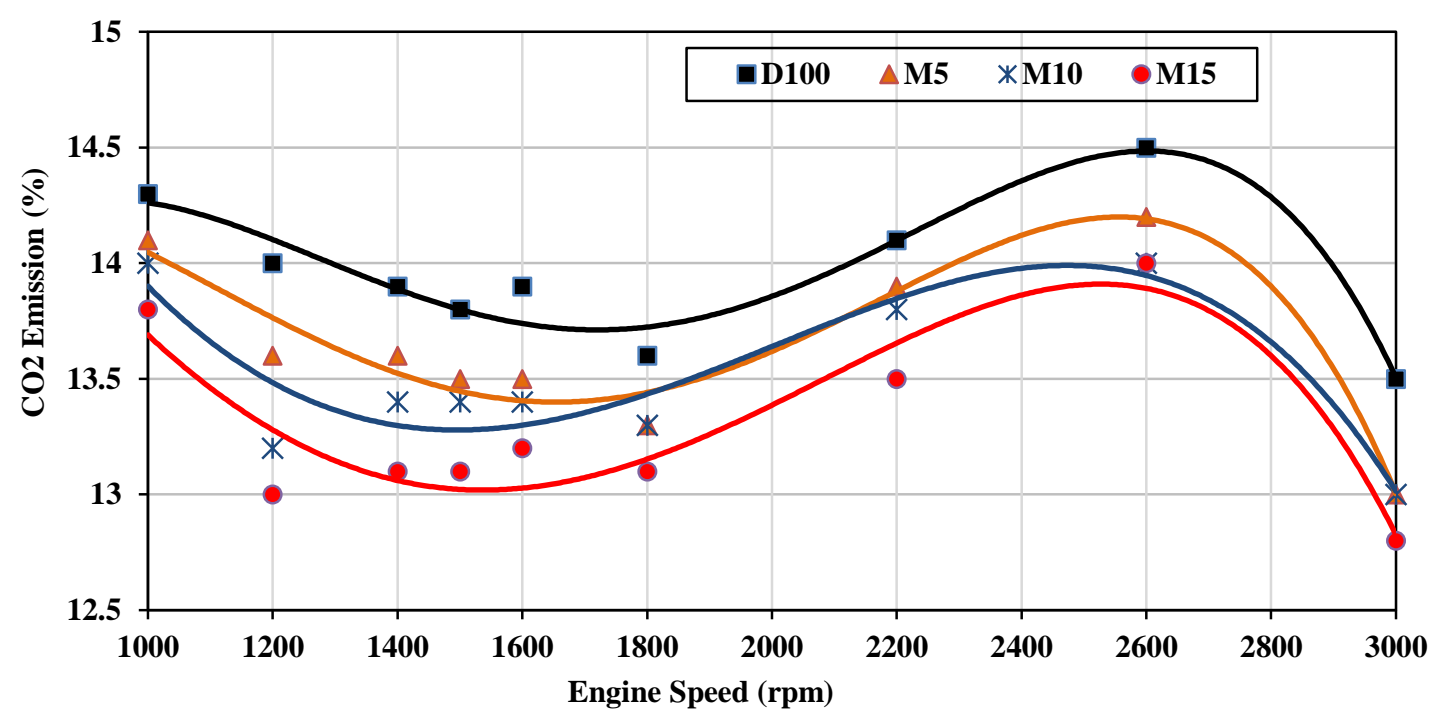

Fig. 4 The values of $\mathrm{CO} 2$ emissions belonging to the test fuels

The addition of methanol results in an average decrease of $7.6 \%, 12.66 \%$ and $38.4 \%$ in the $\mathrm{CO}$ emissions of the blends, respectively. Fig. 5 indicates the effect of the methanol added to diesel fuel on $\mathrm{CO}$ emission. The decrease in the $\mathrm{CO}$ emission can be explained that the oxygen existed in the chemical structure of methanol $(\mathrm{CH} 3 \mathrm{OH})$ reacted with more $\mathrm{C}$ atoms, and transformed into $\mathrm{CO} 2$.

Exhaust gas temperature is an important parameter for emission occurring and interpretation. For example, high exhaust gas temperature refers to high amount of the consumed fuel. Fig. 6 shows the effect of methanol on the exhaust gas temperature. The diesel-methanol blends yielded an average increase of $1.77 \%, 2.5 \%$ and $3.66 \%$ in the exhaust gas temperature compared to those of diesel fuel. The reason of the increase is that the oxygen existed in the methanol increases the burning quality and rate.

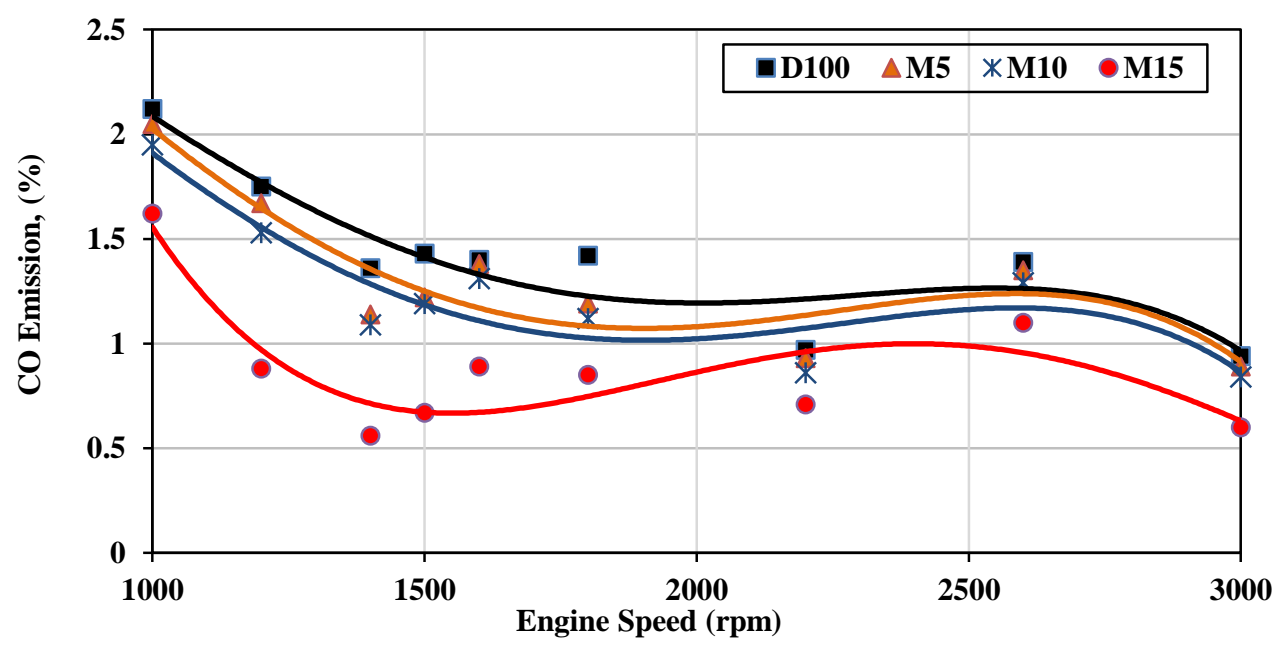

Fig. 5 The values of $\mathrm{CO}$ emissions belonging to the test fuels

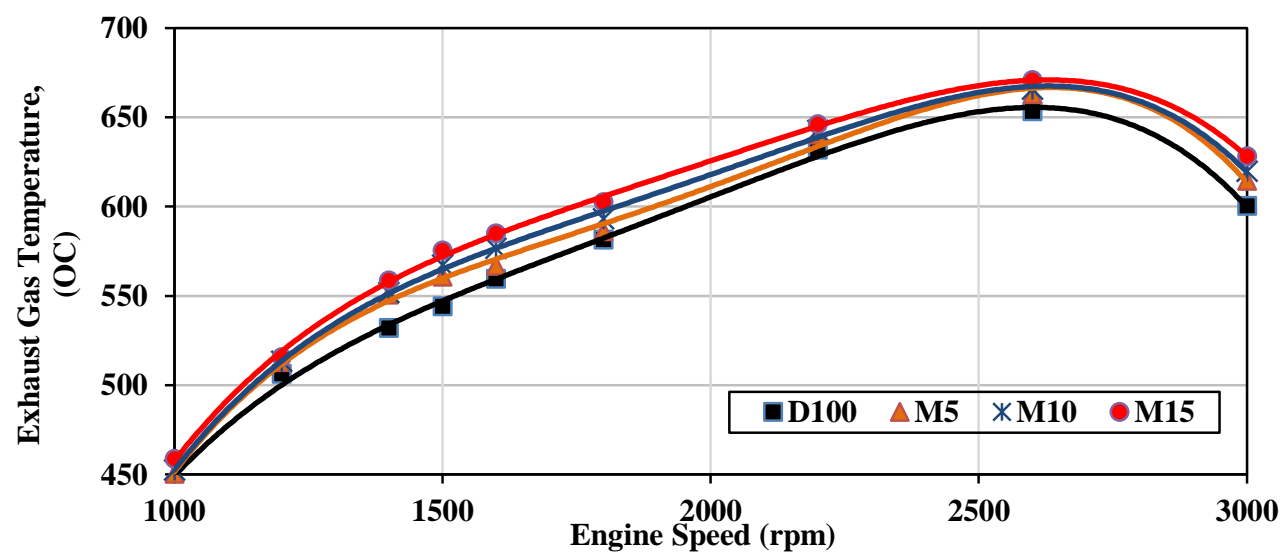

Fig. 6 The effect of methanol on the exhaust gas temperature 
Nitrogen and oxygen, which may not interact with each other at low temperatures, react and yields NOx (NO and NO2) compounds [8]. The nitrogen oxide compounds yielded causes acid rains [9]. Fig. 7 represents the effect of methanol on NOx emission yielding. The addition of methanol yielded an average increase of $6.5 \%, 10.78 \%$ and $17.1 \%$ in the NOx emission, respectively. The facts that methanol increased the exhaust gas temperature and consisting of high amount of oxygen are said to be the reason of the increase in NOx emission.

Opacity of smoke indicates burning quality, and a smog resulted from the burning process is the indication of too much carbon residue (deposit of soot) remained inside the burning products. Because methanol has cleaner burning characteristics due to its content of oxygen, the addition of methanol yielded an average decrease of $13.2 \%, 31.6 \%$ and $39.37 \%$ in the opacity of smoke, respectively (Fig. 8). On the other hand, as for the effect of the diesel fuels with the methanol blends on the engine wear and long-term durability, some research on this direction express that the use of the methanol blends has no any negative impacts on engine wear and durability [17].

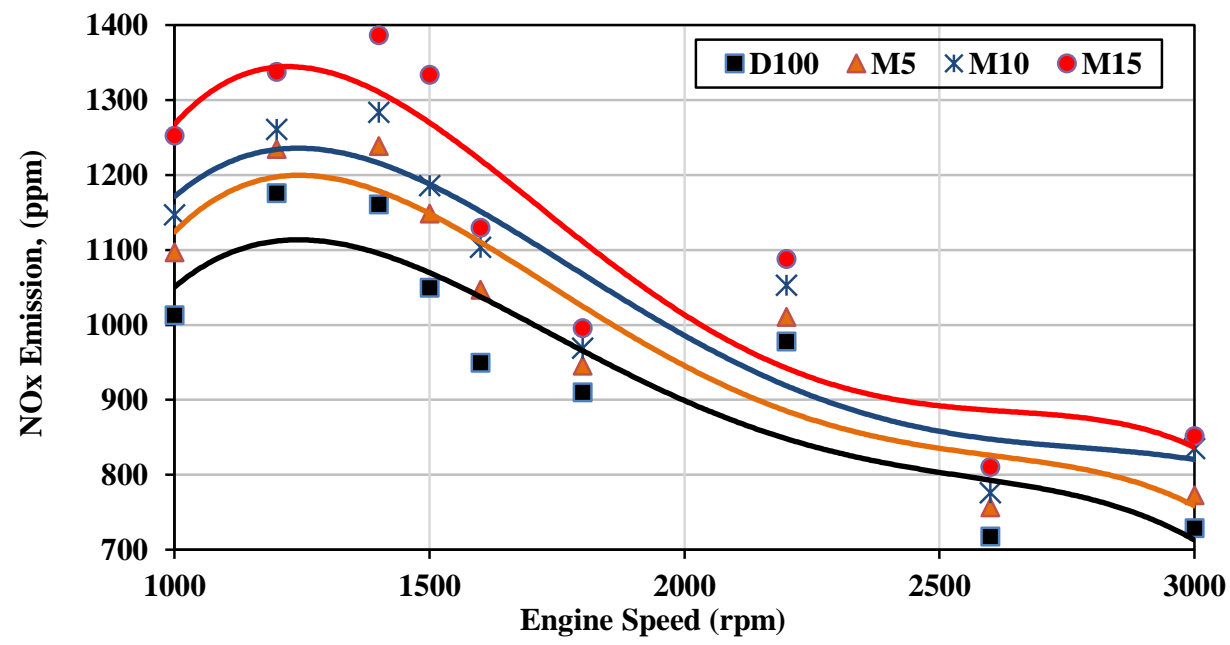

Fig. 7 The effect of methanol on NOx emission

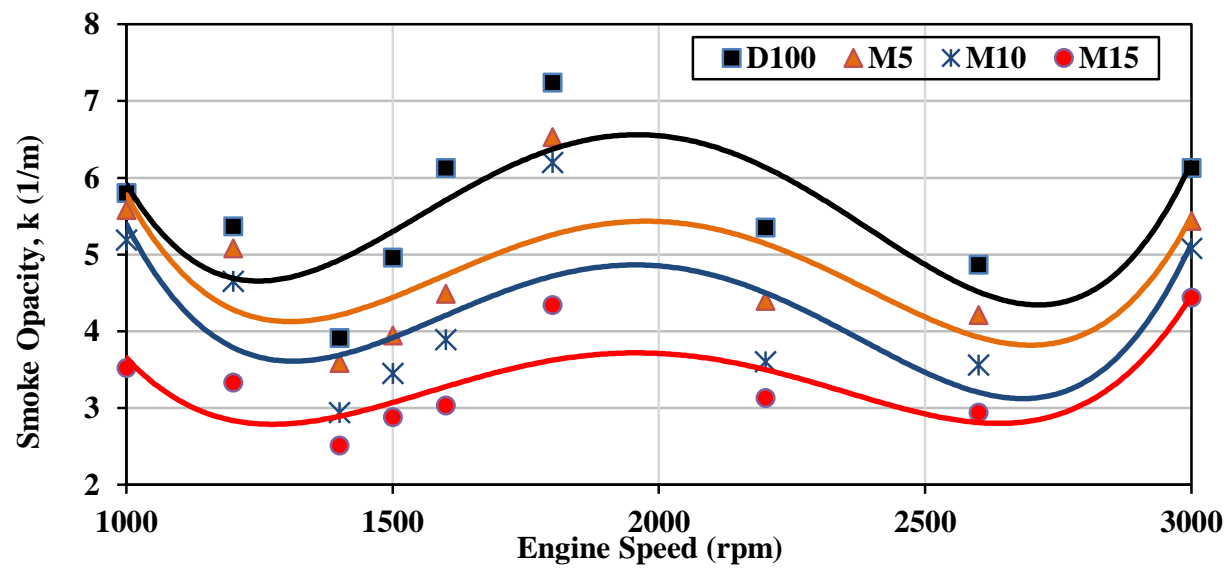

Fig. 8 The effect of methanol on smoke opacity

\section{Conclusions}

The use of methanol added to the diesel fuel in a diesel engine is assessed as follow, in terms of engine performance and environmental effects of methanol in use:

- Diesel fuel and methanol can be homogeneously mixed because of their densities are too close. Also the blends can keep their homogeneity at least 20 days.

- Methanol reduces the parameters of cetane number and heating values of diesel fuel, which are known to be critical for engine performance.

- The fact that diesel blends fueled with methanol has low heating values causes a decrease of around $12-13 \%$ in the engine performance.

- Methanol, consisting of lower $\mathrm{C}$ atoms and a high amount of oxygen, resulted in lower $\mathrm{CO} 2$ and $\mathrm{CO}$ emissions at the end of combustion.
- The fact that the burning rate of methanol due to its content of oxygen causes the exhaust gas temperature to increase.

- As understood from the increase in the exhaust gas temperature, the increase in the burning temperature of methanol increased NOx emissions.

- Methanol having cleaner burning characteristics due to its content of oxygen resulted in a decrease in the opacity of smoke.

As a result, even if the diesel-methanol blends consisted of low amount of methanol, the blends provided significant contributions for enhancement of environmental impacts of hazardous exhaust emissions, whereas they cause even a little negative effect on the parameters of engine performance. 


\section{References}

1. Brusstar, M.; Stuhldreher, M.; Swain, D.; Pidgeon, W. 2002. High efficiency and low emissions from a port-1njected engine with neat alcohol fuels, Society of Automotive Engineers, 01-2743.

https://doi.org/10.4271/2002-01-2743.

2. Mat-Yasin, M. H.; Mamat, R.; Yusop, Ahmad F.; Aziz, A.; Najafi, G. 2015. Comparative study on biodiesel-methanol-diesel low proportion blends operating with a diesel engine, the 7th International Conference on Applied Energy - ICAE2015 Energy Procedia 75:1016. https://doi.org/10.1016/j.egypro.2015.07.128.

3. Şeker, S. 2007. Investigation of Biodiesel Production and Effects of Additives on Fuel Properties, MSc Thesis, Chemical Engineering Department, Gazi University Institute of Science and Technology November.

4. Bechtold, R. L.; Goodman, M. B.; Timbario, T. A. 2007. Use of methanol as a transportation fuel, The Methanol Institute, Technical Report, Arlington, VA 22203.

5. Alliance. 2008. Methanol Safe Handling Manual, Methanol Institute, Technical Report, Arlington, Virginia.

6. Najafi, G.; Yusaf, T. F. 2009. Experimental investigation of using methanol-diesel blended fuels in diesel engine, Proceedings of the Fourth International Conference on Thermal Engineering: Theory and Applications January 12-14, Abu Dhabi, UAE.

7. Suresh, R.; Durgaprsad, B.; SenthilKumar, P.; Albert, M. 2010. Performance analysis for emission and combustion of methanol blend diesel fuel in ci engine using glow plug, 978-1-4244-9082-0/10/\$26.00 (C2010 IEEE. https://doi.org/10.1109/FAME.2010.5714825.

8. Weitao, C. 2008. The experimental study about the influence of methanol/diesel fuel mixture on diesel engine performance, Workshop on Power Electronics and Intelligent Transportation System, 978-0-7695-3342- 1/08, IEEE. https://doi.org/10.1109/PEITS.2008.118.

9. Joshua, M. P.; Balamurali, S.; Prashanth, S. 2016. Experimental investigation of methanol-diesel blends as alternate fuels for compression ignition engines, International Journal of Current Engineering and Technology, $6(3): 1-4$. https://doi.org/10.14741/Ijcet/22774106/6.3.2016.36.

10. Kwanchareon, P.; Luengnaruemitchai, A.; Jai-In, S. 2007. Solubility of a diesel-biodiesel-ethanol blend, its fuel properties, and its emission characteristics from diesel engine, Fuel, 86:1053-61. https://doi.org/10.1016/j.fuel.2006.09.034.

11. Ciniviz, M.; Köse, H.; Canli, E.; Solmaz, O. 2011. An experimental investigation on effects of methanol blended diesel fuels to engine performance and emissions of a diesel engine, Scientific Research and Essays 6(15):3189-3199. https://doi.org/10.5897/SRE11.230.

12. Gopinath, V.; Shanmughasundaram, P.; Suresh, P. 2017. Performance and emission characteristics of a diesel engine runs with corn oil biodiesel blends and air pre heater, Mechanika 23(3): 462-468. http://dx.doi.org/10.5755/j01.mech.23.3.14853.

13. Arumugam, K.; Maran, P.; Aravındhan, K.; Sornakumar, T. 2018. Effect of additional air supply for combustion of straight vegetable oil blends on performance of mini hot water generator, Mechanika 24(2): 278-283.

http://dx.doi.org/10.5755/j01.mech.24.2.19783.

14. Bayraktar, H. 2008. An experimental study on the performance parameters of an experimental CI engine fueled with diesel-methanol-dodecanol blends, Fuel, 87: 158-164.

https://doi.org/10.1016/j.fuel.2007.04.021.

15. Sayin, C. 2010. Engine performance and exhaust gas emissions of methanol and ethanol-diesel blends, Fuel, 89: 3410-3415.

https://doi.org/10.1016/j.fuel.2010.02.017.

16. Yao, C.; Cheung, C. S.; Cheng, C.; Wang, Y.; Chan, T. L.; Lee, S. C. 2008. Effect of diesel/methanol compound combustion on diesel engine combustion and emissions, Energy Conversion and Management 49:1696-1704. https://doi.org/10.1016/j.enconman.2007.11.007.

17. Likos, W. E. 1984. The effect of alcohol fueling on diesel engine durability, SAE Transactions 93 (6): 51-56.

\section{A. Berber}

THE EFFECT OF DIESEL-METHANOL BLENDS WITH VOLUMETRIC PROPORTIONS ON THE PERFORMANCE AND EMISSIONS OF A DIESEL ENGINE

S u m m a r y

In this work, the methanol is added to the diesel fuel in the volumetric proportions of 5\%-\%10-\%15 to diminish negative environmental impacts of diesel engines. The diesel-methanol blends in the various proportions are tested in a single-cylinder direct-injection diesel engine. According to the test results, the addition of methanol to the diesel fuel causes a maximum decrease of $13.07 \%$ in the engine torque, and a maximum decrease of $12.54 \%$ in the specific fuel consumption. On the other hand, the exhaust emission results show that the values of $\mathrm{CO}$ and $\mathrm{CO} 2 \mathrm{de}-$ crease $38.4 \%$ and $5.04 \%$. However, the increase of $3.66 \%$ in the exhaust gas temperature causes the increase of $17.1 \%$ in the NOx emission. Also, a significant decrease of $39.37 \%$ in the smoke opacity is observed compared to that of the diesel fuel. Although the addition of methanol to diesel fuel causes a slightly decrease in the engine performance, the diesel-methanol blends have a reasonable and considerable positive effect on environmental concerns of diesel engines.

Keywords: Ddiesel-methanol blends, exhaust emissions, diesel greenhouse effect, air pollution, engine performance.

Received March 13, 2019 Accepted October 14, 2019 